\title{
Key Conceptual Threads in Ukrainian Canadian Ethnography
}

\author{
Andriy Nahachewsky \\ University of Alberta
}

\begin{abstract}
Ukrainian ethnography has been a large, diffuse field of activity in Canada, with several identifiable threads. The field's significance has been primarily cumulative rather than evident in individual field-changing works. Robert Klymasz's PhD dissertation ("Ukrainian Folklore in Canada," 1971) on continuity and change in Ukrainian Canadian culture is the main exception. Some studies have dealt with traditional culture in Ukraine, but the mainstream of Ukrainian Canadian ethnography has focused on Ukrainian cultural activities documented in Canada itself. Within these Canadian materials, many scholars have allowed for, and even celebrated, the processes of adaptation, hybridity, and creativity in Ukrainian Canadian culture. Ukrainian Canadian ethnography has been strongly integrated with North American scholarship in general, but until recently it was poorly connected with folkloristics and ethnology in Ukraine. Canadian ethnography has potential to contribute to Ukraine's ethnology and folkloristics through its nuanced elaboration of the importance of context and its documentation of processes of cultural change and hybridity, urban traditions, ethnic identity and revival, and multicultural relations.
\end{abstract}

Keywords: Ukrainian Canadian ethnography, folklore, ethnology, continuity and change, research.

Canada's Ukrainian community has the most developed record of ethnographic scholarship of all the countries around the world with

Ukrainian diasporic populations. This has undoubtedly been influenced by a number of facts: a large and somewhat clustered population; 125 years of history, including a large, deeply rooted farming population; the emergence of academic Ukrainianist positions; and a series of supportive contextual factors in Canada. Ukrainian Canadian ethnography has been reviewed in a number of publications (Melnyk 8-20, 24-25; Medvids'kyi, "Zbyrannia" and "Katedra," 58-75; Nahachevs'kyi and Maierchyk; Nahachewsky, "Fol'klor") and bibliographic compendia (Klymasz, $A$ Bibliography, with 463 entries; parts of Klymasz, "University"; and in the above articles).

This paper focuses on key substantive threads in Ukrainian Canadian ethnography since 1950 . In contrast to previous reviews, the structure of this article is not primarily chronological. Instead I survey Ukrainian Canadian ethnographic work according to several key conceptual 
perspectives on the subject matter. I concentrate on published works and graduate research by Ukrainian Canadian ethnographers where theoretical perspectives tend to be defined and explicit. I propose five conceptual threads defined by the core time and location of the ethnographic subject: two of these have Ukraine as the ideal location, first in the distant past, and second in the "classical" folk culture of peasant villages from previous centuries. The third thread shifts attention to Ukrainian experience in Canada, idealizing the retention of pre-immigration culture. The fourth thread highlights hybridity and change over time in Canada. The fifth thread concentrates on the ethnographic present. Four additional threads are identified briefly because of the frequency of their thematic concerns: studies with geographic focus, studies of material culture, ethnic revival activity, and ethnic identity. I understand that these categories constitute a somewhat superficial analysis of ethnographers' values and concepts. ${ }^{1}$ The threads are not mutually exclusive, though contrasts are emphasized here for heuristic purposes. I argue that these threads reveal important patterns that deserve our attention if we aim to understand Ukrainian Canadian ethnography.

This grouping exercise is preceded by two subsections: first I present my understanding of the term "ethnography"; then I acknowledge the particular importance of collecting and archiving activities. Concluding comments touch upon relations between Ukrainian ethnography in Canada and Ukrainian ethnography in Ukraine.

\section{ETHNOGRAPHY}

In this article the term "ethnography" refers broadly to the study of non-elite culture using fieldwork methods-direct contact with the people who live the culture being studied. I concentrate mostly on academic ethnography, although I strive to downplay the false dichotomy between scholarly and non-scholarly work especially in this area, which engages with people beyond the academy by its very definition. Many contrasting approaches to the term "ethnography" have been articulated, with especially significant theoretical debates since the 1970s. This article does not explore these

\footnotetext{
${ }^{1}$ Deeper and more specific analyses concentrating on numerous conceptual issues in ethnographic theory over the last half century and their reflections in Ukrainian Canadian ethnography remain worthwhile goals for the future. Such issues include ethnographic poetics, reflexivity, confessional ethnography, hegemony, representation, memory, ownership, indigeneity, feminist perspectives, postmodern perspectives, disciplinary traditions, and ethics.
} 
elaborations; it modestly describes certain specific trends that have been important in Ukrainian Canadian ethnography.

"Ethnography" refers to both the research method and the materials produced from this fieldwork in any given project. Ethnographic methods are used in anthropology, folklore studies, folklife studies, cultural studies, certain approaches in sociology, human ecology, history, nursing, and other North American scholarly disciplines. Many Ukrainian Canadian ethnographies have been folkloristic in nature, but not all. Folklorists have long focused on peasant and rural culture, though for much of the twentieth century this discipline has had a much larger scope in the Western world, encompassing potentially any subgroup within society. Ethnographic field methods tend to be qualitative and intensive, encouraging thick description. When associated with Ukrainian studies, ethnography tends to extend into the study of non-elite culture using other research methods. In Ukraine ethnography has been associated with fol'klorystyka, etnolohiia, kul'turolohiia, and narodoznavstvo. Sometimes, as with narodoznavstvo (people's studies, national studies, folk studies), ethnography has carried a connotation of nation-building activism. Fol'klorystyka (the study of verbal lore and expressions of belief) and etnohrafiia (material culture and nationorigin studies) have typically been organized as separate disciplines in eastern Europe (in philology and history departments, respectively), but these fields have been thought of as a single discipline in North America. Further, in this article ethnography is not specifically contrasted with ethnology, as it often is in Ukraine, where ethnography implies a greater focus on collecting information and writing out descriptions (-graphy) and ethnology implies the pursuit of analysis-scientific study (-logy). Ethnology has a higher status. Finally, I reject the notion that the term "ethnography" should be restricted to the study of a single culture, in contrast to "ethnology," which some scholars propose as fundamentally comparative. The ethnographic study of Ukrainians in Canada and all diaspora research must be contextual and transcultural at heart. Ethnographic research has a core disciplinary centre but few discrete margins.

\section{COLLECTION AND ARCHIVING}

In ethnography, often more so than in other academic disciplines, the data collection phase is complex and resource-intensive. A great deal of focus is placed on observing, collecting, preserving, and documenting cultural texts in various media. Ethnographic studies tend to be inductive; thus most of the explicit analysis/theorizing follows and may be separate from the phase of active interaction with the culture bearers. Indeed, 
ethnographic/folkloric/cultural archives have often been assembled over decades or centuries, thereby involving a great investment, even when the collectors could not imagine what the research questions might be in the future. The "secondary" use of ethnographic materials from archives and from earlier publications presents its own challenges though such collections may well be valuable for the research goals of others: they may give access to additional variant texts, provide insights into distribution, suggest further fieldwork strategies, and raise new questions and theories.

Several Canadian universities maintain collections of Ukrainian ethnographic descriptive materials, each with websites and other tools to assist researcher access. At the University of Manitoba, the Centre for Ukrainian Canadian Studies at St. Andrew's College and the Archives of the Ukrainian Canadian Experience hold significant collections of Ukrainian Canadian ethnographic material. St. Thomas More College at the University of Saskatchewan hosts the Prairie Centre for Ukrainian Heritage. The University of Alberta is home to the Peter and Doris Kule Centre for Ukrainian and Canadian Folklore (aka the Kule Folklore Centre), with its Bohdan Medwidsky Ukrainian Folklore Archives. Cape Breton University and other Canadian universities contain materials pertaining to their local Ukrainian communities.

A number of governmental and private institutions house collections with Ukrainian Canadian ethnographic content, including the Library and Archives Canada in Ottawa; the Canadian Museum of History (formerly the Canadian Museum of Civilization) in Gatineau; the Ukrainian Canadian Research and Documentation Centre and the Multicultural History Society of Ontario in Toronto; the Ukrainian Cultural and Educational Centre (Oseredok) in Winnipeg; and the Ukrainian Museum of Canada in Saskatoon, which has several branches across the country. The Ukrainian Cultural Heritage Village, located fifty kilometres east of Edmonton, preserves a large artefact collection to support its museological mission and has audio records and other research documentation regarding Ukrainian rural life in Alberta up to the 1930s. Dozens of smaller archives and museums with Ukrainian ethnographic materials exist in cities, towns, and villages across Canada. Many private collections are also valuable to ethnography research.

Additional ethnographer aids are film references to Ukrainians in Canada (Zaporzan and Klymasz), Ukrainian Canadian newspapers (Swyripa, Guide), oral histories (Swyripa, Oral Sources), and Canadian archives generally (Matiash).

All archives, museums, and private collections were founded on and operate on particular theoretical foundations: conceptualizations of what archives and museums should be; ideas about their specific goals, scope, and mandate; beliefs about what is less valuable and why; understandings of how the items should be collected and preserved; considerations of what 
metadata are important; and priorities for presentation and access (cf. Cherniavs'ka 89-91, 97). These theoretical positions change from time to time. However, because of the greater emphasis on collection than on analysis, institutions may not make theoretical differences explicit.

\section{INFORMALITY OF THE INTELLECTUAL THREADS}

Ukrainian Canadian ethnography has not developed dedicated and consistent publishing venues. Monographs have been published infrequently and by various publishers, including the Canadian Institute of Ukrainian Studies Press, the Kule Folklore Centre, the University of Manitoba Press, McGill-Queens University Press, the University of Calgary Press, and the University of British Columbia Press. A number of ethnographic studies have been published through the Shevchenko Scientific Society in Canada, in festschrifts (Kukharenko and Holloway; Nahachewsky and Chernyavska) and special volumes (cf. Makar and Bilash). Journals with relevant content include Folklorica, edited from 2006 to 2012 by Natalie Kononenko; Narodna tvorchist' ta etnohrafiia (Kyiv); Narodoznavchi zoshyty (Lviv), Canadian Slavonic Papers; Ethnologies (formerly Canadian Folklore Canadien); and the Journal of American Folklore. In addition to occasional articles, the Material History Bulletin (The Ukrainians in Canada 1989), the Journal of Ukrainian Studies (Ukrainians in Canada 1991), and Canadian Ethnic Studies (The Ukrainian Canadians 2015) have produced special issues related to Ukrainian Canadians that contain ethnographic content. Many scholarly, semischolarly, and popular publications in diverse formats have been issued by a host of active Ukrainian Canadian organizations or published directly by the authors. Such a diversity of authors, publishers, and audiences has not supported any formally sustained and recognized schools of thought or intellectual debate.

We might search for schools of thought in graduate research, since advanced students cluster around university departments and particular professors as they pass through their programs. Some seventy master's theses and doctoral dissertations with a Ukrainian ethnographic focus have been completed in Canada (cf. Klymasz, "University"; Nahachevs'kyi and Maierchyk; Nahachevs'kyi, "Fol'klor"). Graduate theses have been perhaps disproportionately important in Ukrainian Canadian ethnography in comparison with other fields. Andriy Nahachewsky, Bohdan Medwidsky, Natalie Kononenko, Jaroslav B. Rudnyckyj (Jaroslav B. Rudnyćkyj, 1910-95), and other Ukrainianist professors have each served multiple times as supervisors of graduate students who were using ethnographic methods. Robert B. Klymasz, Radomir Bilash, and others have also been key 
facilitators and inspirers of younger scholars. Still, Ukrainian ethnographic research in Canada cannot be described as fitting into clear "schools." The fifty graduate students who have completed theses and dissertations on Ukrainian folklore at the University of Alberta from 1980 to 2016 have each typically chosen his or her own topic, methods, and theoretical framework. Graduate students selecting Ukrainian ethnographic topics in other programs across the country have worked with their supervisors in relative isolation. However, a number of key threads can be identified over time and space.

\section{KEY THREAD 1: ANCIENT UKRAINIAN SPIRITUAL ROOTS}

Interest in an autochtonous spiritual culture-a unique and ancient Ukrainian "national spirit" - has linked ethnography and the Ukrainian national movement for over a century. Stepan Kylymnyk's five-volume study of Ukrainian calendar customs and their ancient mythological significance (1955-64 [1994]) and Dokhrystyians'ki viruvannia ukrains'koho narodu [Pre-Christian beliefs of the Ukrainian people] by Metropolitan Ilarion (1965 [1994]) serve as classic examples of ethnographic writing in this tradition. Both Kylymnyk (1889-1963) and Ilarion (Ivan Ohiienko, 18821972) were educated in Europe and lived in Canada after the Second World War, in Toronto and Winnipeg, respectively. Both scholars were committed to romantic nationalist ideas about the uniqueness of the Ukrainian national character, about the resilience of the Ukrainian spirit over millennia, that this spirit can be at least partially reconstructed from surviving peasant customs and beliefs, and that (re)birth and cultivation of this national spirit is important for a successful political future for Ukraine. Both Kylymnyk and Ilarion had advanced philological and historical training and large personal libraries; thus they were able to provide many comparative examples to strengthen their arguments. Kylymnyk claimed a reliance on ethnographic fieldwork as well (1 [1955]: 8).

Scholars working in this vein were strongly influenced by the "comparative school" in early anthropological and folkloristic thinking and relied heavily on nineteenth-century scholarship (both Slavic and western European) and its theories about unilinear cultural evolution, ancient sun cults, cults of ancestors, and pagan fertility rituals, made famous by Max Müller, Edward Burnett Tylor, James George Frazer, and others. These theories were mostly discounted in the first half of the twentieth century by Western anthropological and folkloristic scholars. However, Ukraine's unfinished nation-building process continued to provide a supportive environment for such arguments during many decades of the twentieth century. Following this established thread, George Foty, Wasyl Niniowsky, 
Orysia Tracz, and others produced studies to highlight pagan roots and pagan-Christian dualism in Ukrainian culture. This perspective has been significant for the Ukrainian community's ethnic revival since the 1970s, and echoes of it can be found frequently in diverse media in Ukrainian Canadian popular culture. Together with the many publications about embroidery designs, customs, rituals, and other genres, those describing Easter eggs have been particularly productive in this vein (cf. Onyshchuk). Mariya Lesiv (The Return) has contributed important insights into the phenomenon of contemporary interest in pre-Christian Ukrainian culture and Ukrainian neo-paganism, using contemporary anthropological and folkloristic lenses to explore it as a cultural construct.

\section{Key Thread 2: “Classical” Ukrainian Folk Culture}

The second thread in Ukrainian Canadian ethnography is related to the first. It has emphasized the value and depth of Ukrainian folk culture but has been less ideologically specific. Authors writing in this style have been less explicit in arguing for primordial origins but have remained committed to presenting and classifying traditional texts from peasant culture in Ukraine. Publications of this type, including international collaborations (cf. Ianiv; Zubryts'kyi), appeared quite early in Canada and have been common until today. They have often been presented in English translation or written in English to provide information for a broader audience that does not read Ukrainian. They have dealt with oral tradition (cf. Livesay; Tarnawsky and Kilina; Osborn; Shiyan), customs and ritual (cf. Maruschak), performance genres (cf. Moroz), material culture (cf. Odarchenko et al.), and other genres (cf. Stechishin; Lohvyn). In some cases older ethnographic texts (cf. Kolessa) have been reprinted providing access to a new generation. In academic research projects, these authors may have applied additional and newer analytical frameworks to their corpus of materials, but presenting the corpus of texts themselves has been understood to be of key importance.

Like thread 1, this type of ethnography has depended primarily on published secondary sources rather than on an author's own fieldwork materials. Only a few postwar émigré scholars (such as Kylymnyk) or later immigrants (such as Shostok [Shostak]) have written substantial studies in Canada based on their pre-emigration fieldwork.

The production of Ukrainian ethnographic materials in Canada was strongly influenced by the Cold War. On the one hand, Canadian ethnographers were not allowed to travel to rural Ukraine. On the other hand, Soviet Ukrainian folklorists and ethnographers produced a great many compilations of folklore texts of many genres, particularly during the decades after World War II. These became increasingly accessible to 
Ukrainian Canadians through specialized bookstores, academic libraries, and via tourists returning from Soviet Ukraine. Ethnographers in Canada could draw from pre-Soviet, diaspora, and Soviet publications to create compilations of their own and apply secondary analytical methods. For example, in 1985 Lesia Maruschak completed a thesis detailing the many ceremonial elements of Ukrainian folk weddings in the nineteenth and early twentieth centuries. Her bibliography is extensive and almost entirely European, and she developed a large appendix analyzing the geographic distribution of the various traits across Ukraine. Her project did not involve her own fieldwork.

For Western researchers, fieldwork projects in Ukraine became possible only in the late 1980s with the reforms in the Soviet Union, and thereafter in independent Ukraine. None of the Ukrainian Canadian ethnographers who completed their PhDs prior to Ukrainian independence travelled to Ukraine for their own doctoral projects. Klymasz dedicated his career almost entirely to Ukrainian traditions in Canada. In his dissertation and later folkloric publications, Medwidsky used printed materials from Ukraine, focused on historiography, or attended to Canadian lore. At the start of her academic career in the United States, Kononenko wrote a dissertation (1976) on Turkish epic songs. Only later, and particularly after she became the Kule Chair in Ukrainian Ethnography at the University of Alberta in 2004, did she travel to conduct fieldwork in Ukrainian villages, mostly in central Ukraine and more recently in Kazakhstan (cf. Kononenko, Ukrainian Minstrels and "Ukrainian Folklore"). I was unsuccessful in my efforts to travel to Ukraine for my dissertation in the mid-1980s and focused on kolomyiky in Ukrainian Canadian folk dance instead (Nahachewsky, "The Kolomyika"). I did travel to Ukraine and made brief recordings in the late 1970s, visited Ukrainian communities in the countries around the edges of western Ukraine in the 1980s, and conducted several larger fieldwork projects in Ukraine proper in the 1990s (cf. Nahachewsky, "Searching") and more recently in Brazil (Hrymych et al.). In contrast, graduate students working in the post-Soviet period have had much more flexibility to travel between Canada and Ukraine to collect new ethnographic materials in diverse settings in Ukraine (cf. Kukharenko, "Abnormal"; Khanenko-Friesen, Ukrainian Otherlands; Lesiv, The Return; Olijnyk; Oylupinar; Yakovlyeva).

A number of ethnographic projects dealing with "classical" Ukrainian folk culture involved interviews in North America, in which people were asked to remember Ukrainian rural traditions prior to emigration (cf. Odarchenko et al.; Boichuk). This strategy has been infrequently applied in substantial ethnographic projects. It has been used more often in shorter student papers, recordings of personal experience narratives, oral histories, and descriptions of particular genres or contexts. With few exceptions, these documents have tended to be stronger in description than in analysis. Their 
results have found their way into archival collections (and in museums and on stages) more frequently than in published texts. Contemporary theory about memory, nostalgia, reflexivity, diaspora, and ethnic representation holds great potential for revealing more about the nature of these recordings.

\section{Key THREAD 3: UKRAINIAN CANADIAN EXPERIENCE-CONTINUITY}

A key characteristic of threads 1 and 2 in Ukrainian Canadian ethnography is that they have been centred on the study of Ukrainian culture in Ukrainebut produced abroad, in Canada. The following threads shift the paradigm substantially and involve ethnographies about Ukrainians living in Canada. This category is clearly dominant quantitatively and qualitatively in Ukrainian Canadian ethnography. The research conclusions and project design in the works of some Ukrainian Canadian ethnographers indicate that they are particularly interested in demonstrating continuity with preemigration lore.

Early examples of Canadian collectors who emphasize continuity include Tetiana Koshetz (Koshyts', 1892-1966), who collected approximately two hundred songs in Manitoba in the first half of the twentieth century as part of her job at the Ukrainian Cultural and Educational Centre (Oseredok) in Winnipeg (cf. Klymasz, A Bibliography 23, 52). Volodymyr Plaviuk (1886-1961) collected a large corpus (two volumes) of proverbs in Alberta; Nick Evasiuk collected jokes and tales; and Roman Fodchuk used his own extensive collection of tools to present information about traditional rural material culture. Many other researchers throughout the twentieth century collected similar texts, with clear links to folk tradition in Ukraine (cf. Koszarycz; Nahachevs'kyi, Pobutovi tantsi). Their goals have been to demonstrate the continuity and preservation of traditional Ukrainian culture in the diaspora setting. Admittedly, such processes of preservation were easier to demonstrate in the earlier part of the twentieth century than in the twenty-first. These projects remain relatively compatible with threads 1 and 2 and are generally consistent with ideals of romantic nationalism and Ukrainian nation building.

\section{KEY THREAD 4: UKRAINIAN CANADIAN EXPERIENCE-HYBRIDITY AND CHANGE}

Robert B. Klymasz has played a profound role in Ukrainian Canadian ethnography and folklore in that he made extensive field recordings in the 
1960s and later (cf. Svieto and Ukrainian Folksongs), elaborated on the theory of adaptation and immigrant folklore in his doctoral dissertation (1971), and produced numerous publications to develop and popularize these ideas. He was influenced by his MA supervisor Jaroslav B. Rudnyckyj, who had collected and written about Ukrainian Canadian folklore (cf. Materiialy) while Klymasz was studying in Winnipeg, and later by his doctoral supervisor Richard Dorson, who proposed a "hemispheric theory" of folklore in the New World. This focus on "continuity and change" (with particular interest in change) has defined the main stream of Ukrainian Canadian ethnographic thinking since that time (several works feature this phrase in their titles: Klymasz, Continuity; Lupul, Continuity; Sochan). These ideas have been continually elaborated and updated.

Though Klymasz is undoubtedly the most influential Ukrainian Canadian ethnographer to date, he was not the first to show an interest and understanding of innovation and hybridity. In particular, his MA thesis supervisor Rudnyckyj had collected and published four volumes of diverse folklore texts in the Canadian Prairies, many of which were clearly selected to illustrate Canadian influence. Significantly, the very earliest publications (Hnatiuk; Fedyk) where Ukrainian Canadian ethnographic materials were recorded are focused on Canadian content.

Earlier studies following this thread tended to deal with verbal lore, as examplified above (and cf. Koszarycz; Kononenko, "Ukrainian Ballads"). Many subsequent studies have documented continuity and change in customs, rituals, and beliefs (Sochan; Chernevych; N. Foty), performing arts (Kravchuk; Nahachewsky, "The Kolomyika"; Cherwick, "Polkas"), and material culture (Lazarowich; Medvids'kyi, "Na odnomu"; Lesiv, "From Ritual"; Cheladyn). Performing arts and material culture have been particularly suited to demonstrating continuity and change because they are intricately implicated in their surrounding physical context. These research projects represent a clear break from the romantic nationalist perspective but accommodate contemporary North American ethnographic theories about context, memory, nostalgia, reflexivity, diaspora, and ethnic representation more than the projects described in threads 1-3.

\section{Key Thread 5: The EThNographic PRESENT}

Whereas the focus of research in threads 1-4 has been historical and diachronic, the fifth thread in Ukrainian Canadian ethnography deals with culture in the present. Studies of the ethnographic present are preferred in many humanities and social sciences because of the directness of researcher access, the richer multi-sensory engagement with the subject matter and its context (in contrast to the thinner stream of information that comes from 
imagining an event from the past that is described in writing or verbally during an interview), and the ability to collect new types of data. Participant observation is a core research method in this approach. Scholarship on the ethnographic present reduces complexity from factors such as memory, nostalgia, reflexivity, and age. Researchers working in this thread do not necessarily interview elderly or marginal people (as is normal in threads 2, 3 , and 4). Instead they often find cultural insiders of all ages who might provide rich information on the topic.

A few early twentieth-century publications (Hnatiuk; Fedyk) presented synchronic views of cultural texts that were contemporary at the time. This research style was less common in the middle of that century, except perhaps in ethnographic films (Boulton; Klymasz, Luchak's Easter). When shooting footage for these films, however, the directors still chose contemporary scenes that had an archaic feeling.

This research approach has been revived in recent years. In writing Salt and Braided Bread, Jars Balan travelled to Ukrainian communities across Canada to characterize special features of contemporary local life from sea to sea. Sogu Hong's PhD dissertation explored recent Ukrainian weddings in the Edmonton area to see the symbolic elements people use to represent their ethnicity in monoethnic and mixed marriages. Anna Kuranicheva wrote a master's thesis on the diverse kinds of "Ukrainian" objects people display in their living rooms; and Kateryna Kod interviewed a number of Edmonton painters who had recently immigrated from Ukraine. Such synchronic studies of contemporary life have dealt with both urban and rural experiences.

Ethnographers in Canada have produced a few studies of contemporary culture in Ukraine. For example, Svitlana Kukharenko interviewed people in Ukraine for her study of wedding magic beliefs ("Negotiating Magic") and for the recently growing phenomenon of abnormal death memorials in Ukraine ("Abnormal"), while Nataliya Bezborodova studied expressive elements of Facebook posts during the Maidan conflicts.

Threads 1-5 each focus on a particular core time frame for Ukrainian ethnographic subjects: primordial Ukraine; nineteenth-century Ukrainian villages; transplanted immigrant cultural elements; trends in twentiethcentury Canada; and the present. Several further threads focus on different qualities and bring together works that deal with a particular subject, an organizational principle, or a theoretical issue.

\section{KEY THREAD 6: GEOGRAPHY}

The first $\mathrm{PhD}$ dissertation in Canada on a subject that fits our broad definition of ethnography was by John Lehr (1978), entitled "The Process 
and Pattern of Ukrainian Rural Settlement in Western Canada, 1891-1914." (Klymasz received a doctorate in 1971, but at Indiana University.) As a geographer, Lehr frequently spent time in the areas he studied and engaged with the local population's experience of space and place, among other research strategies (cf. Lehr, Ukrainian Vernacular; Community). In an MA thesis in anthropology dealing with the Ukrainian ethnic bloc in east-central Alberta, Radomir Bilash also combined geography and ethnography. Frances Swyripa's Storied Landscapes (2010) is a grounded exploration of geography and ethno-religious identity from a historian's perspective. The Local Culture and Diversity on the Prairies oral-history project was designed to facilitate exploration of the patterns of geographic distribution of Ukrainian cultural elements among Prairie communities (Nahachewsky, Local Culture). Whereas regional diversity has been a long-term major focus of ethnographic research in Ukraine, it has been unusual in Canada.

A number of Ukrainian Canadian ethnographic research projects have focused on a single location or a single community and thus also have a geographic focus. For example, Klymasz amassed substantial archival material on Gimli, Manitoba ("Gimli Community"); Aya Fujiwara explored Opal/Maybridge, Alberta, in her MA thesis; and in her PhD dissertation Natalia Shostak (now Khanenko-Friesen) focused on Mundare, Alberta ("Local Ukrainianness").

\section{Key Thread 7: MATERIAL CUlture AND MuSEOLOGY}

Explorations of Ukrainian Canadian culture often have links with museum projects, perhaps the largest example being the collection of documents and research interviews recorded for the Ukrainian Cultural Heritage Village, as noted above. A dozen of these specially contracted studies have been published in the series Alberta Historic Sites Service Occasional Papers (cf. Lehr, Ukrainian Vernacular; Chorniawy; Lesoway; Klymasz, Svieto). In addition to architecture (also cf. Hunchuck), several studies have dealt with textiles (cf. Lazarowich; Bilash and Wilberg), folk medicine (cf. Hanchuk; A. Klymasz; Mucz), and other genres that include material culture (cf. Fodchuk). In her MA thesis Vita Holoborodko compared the histories, collections, and diverse strategies of three Ukrainian museums in Edmonton.

KEY THREAD 8: ETHNIC IDENTITY 
Discussions of Ukrainian identity in Canada have taken place in history, sociology, anthropology, and other disciplines, including Ukrainian Canadian ethnography. Multidisciplinary conference proceedings, topical collections, and special issues in Ukrainian Canadian studies have frequently contained ethnographic content (cf. Lupul, Heritage; Lupul, Visible Symbols; Lupul, Continuity; Rozumnyj). In their dissertations Brian Cherwick, Marcia Ostashewski, and others have explored how music and identity are intertwined. In her dissertation Sophia Matiasz explored the connections between the Ukrainian Catholic Church and Ukrainian identity in three parishes in Edmonton. In her MA thesis Aya Fujiwara used interviews to explore Ukrainian and Japanese relations. In Inshyi Svit and Ukrainian Otherlands Natalia Khanenko-Friesen provides a nuanced perspective on Ukrainian diaspora consciousness. And in According to Baba, Stacey Zembrzycki explores issues of identity and ethnicity, including Ukrainian subgroup relations, and raises important theoretical issues.

\section{Key Thread 9: ETHNiC REVIVAL, ORGanized CoMmunity ACTIVITY}

Folklore studies and ethnography in Ukraine have typically concentrated on traditional peasant culture. Staged representations of folk song and folk dance, ethnic drama, and other revivalist activities (if they are recognized at all) have often been considered beyond the scope of the discipline and have been called neo-folklore, folklorism, or fakelore. In the West, however, where folklorists have studied the shared culture of any cultural group, urban ethnic organized cultural life falls comfortably within their purview. Ethnographers have developed theoretical tools to understand these complex phenomena. This is especially attractive to many researchers because of the central role of such activities in Ukrainian Canadian ethnic identity (cf. Major; Scott). Indeed, many Ukrainian Canadian ethnographers have been attracted to academic life because they were participants in the cultural revival themselves. In their MA theses Iroida Wynnyckyj and Alexandra Pritz documented and analyzed Ukrainian theatre in Canada. In their PhD dissertations Sylvia Shaw, Andriy Nahachewsky (as well as in his article "Avramenko"), and Marcia Ostashewski focused on Ukrainian staged dance in Canada using ethnographic methods, as have others. Ukrainian music exhibits more continuity between the vernacular tradition and selfconscious staged "revival," and a number of academic studies have engaged ethnomusicological concepts to explain the phenomena at hand (Cherwick, "Polkas" and "Whose Sunshine"; Berthiaume-Zavada).

Numerous other threads in Ukrainian Canadian ethnography may be identified, though they each form smaller clusters of research. Unofficial religious culture might be identified as a thread (cf. Matiasz; Himka et al.), 
and vernacular spirituality is closely related (cf. Hanchuk; Kukharenko, "Negotiating Magic"; Lesiv, The Return). Gender issues have been raised more or less centrally in a few projects (e.g., Sinclair; Ostashewski). Ukrainian Canadian ethnographies have occasionally had an explicit comparative component, contrasting Ukraine and Canada (Shostak; Kukharenko, "Negotiating Magic"), other Canadian ethnic communities (Peacock; Fujiwara; Hong; Nahachewsky, Local Culture), or Ukrainian diaspora communities in other countries (Jensen; Hrymych et al.; Kononenko, "Ukrainian Folklore"). Aesthetics remain a minor thread in Ukrainian Canadian ethnography (but cf. Klymasz, "Crucial"; Cheladyn; Kod). Klymasz ("Male and Female") dabbled intriguingly in psychoanalysis.

A great many memoirs have documented Ukrainian Canadian nonofficial culture in audio, manuscript, and published formats (cf. Chumer; Piniuta). Scholarly analysis of this mostly descriptive memoristic material is not well-developed, though the fields of life writing, memory studies, and oral history in general have potential to provide many insights into these Ukrainian Canadian texts. Among analytical contributions to date, Monica Jensen recorded interviews about Ukrainian Canadian ritual activities with women in two families and found that the family members who had left the Prairies became more articulate than the family members who stayed and continued these practices. Stacey Zembrzycki's According to Baba stands out as a methodologically reflexive oral-history project.

\section{UKRAINIAN CANADIAN ETHNOGRAPHY: BETWEEN UKRAINE AND CANADA}

Obviously the development of Ukrainian Canadian ethnography has had links with Ukrainian territory because of emigration and Ukrainian national consciousness. On the other hand, Ukrainian Canadian ethnography has been decisively Canadian oriented, for a number of reasons.

Substantive ethnographic connections between Canada and Ukraine have been weak. Canadian ethnographic researchers and activists were generally isolated from Ukraine by the Iron Curtain for most of the twentieth century. There was only sporadic and limited direct contact among researchers, with source materials (especially from Canada to Ukraine), and fieldwork/archival access. Ukrainian Canadian folkloristic/ethnographic materials were hardly ever published in Ukraine until the period of Perestroika and after 1991. Even now they remain exotic there. Negative Soviet political clichés dominated for most of the twentieth century, and Canadian evaluations of Soviet Ukrainian folkloric/ethnographic scholarship were generally unflattering as well (cf. Klymasz, "Folklore Politics"). Soviet Ukrainian governments and academic institutions almost 
never provided funding or other support for Ukrainian Canadian studies. This has changed little in post-Soviet times.

On the other hand, Ukrainian Canadian ethnography has had strong and clear links with demographic, ethnographic, museological, academic, financial, and popular realities in North America. A few of the authors listed in the works cited at the end of this article-Metropolitan Ilarion, Kylymnyk, Rudnyckyj, Khanenko-Friesen-were somewhat trained in Ukraine, but even most of those born in Europe-Medwidsky, Kononenko, Lesiv, and others-were trained in folklore or ethnography after arriving in North America. A larger number of scholars-including Klymasz, Bilash, and Nahachewsky-were born in Canada, and several-Boulton, Fujiwara, Hong, Lehr, and Oylupinar-have entirely non-Ukrainian ancestry.

Much of the foundational work for Ukrainian Canadian ethnography was carried out in the 1950s and 1960s by postwar Ukrainian refugees who saw Canada as their new permanent home. The great growth in Ukrainian Canadian ethnography, however, occured during the 1970s, 1980s, and 1990s - a time characterized by Canadian multiculturalism, cultural funding, a broadening academic scope in many universities, and strong growth for Canadian museums and other cultural institutions. The vast majority of ethnographic fieldwork by Ukrainian Canadians has been conducted in Canada. It has been mostly funded by Canadian institutions, many of which have an explicit mandate to focus on Canadian culture.

Ukrainian Canadian fieldwork has been conducted in Ukrainian or English (and occasionally in French), depending on the strongest linguistic connection between the informants and their subject matter (and sometimes on the linguistic limitations of the ethnographer). Publications in Ukrainian have served to present the collected data in the original language, to promote Ukrainian national development, and perhaps secondarily to facilitate access in Ukraine. The great majority of publications, however, have been written in English and oriented toward the non-Ukrainian speaking Ukrainian reader, the general Canadian audience, or the international English-speaking market. Graduate students, even if they have come from Ukraine, have acquired most of their theoretical training based on Western (English-language) theoretical texts. They have adhered to Canadian academic standards, defended their scholarship in front of partially non-Ukrainian committees, secured Canadian funding, and found strategic publishing opportunities mostly in Canada and in English. Ethnographers trained in Canada, including those raised in Ukraine and with very strong attachments there, have almost never found employment in related fields in Ukraine. On the other hand, many have developed successful careers in Canada's academic, museological, communications, arts, and heritage sectors. 
Furthermore, their ethnographic subject matter has often been profoundly affected by other Canadian content and contextual influences. Many research projects have led to conclusions that North American aspects of the Ukrainian Canadian subject matter they study are greater than originally assumed (cf. Kostash; Chorniawy; N. Foty; Lesiv, "From Ritual"; Kukharenko, "Negotiating Magic"; Cherwick, "Whose Sunshine"; Cheladyn). Ukrainian Canadian subject matter has certainly been influenced by each new wave of Ukrainian migration to Canada and by media access from Ukraine, both of which provide new repertoire, designs, and aesthetics, but these factors are now being understood as additions overlaid upon the ethnographic reality, and filtered strongly by diverse biases in each period. Perhaps one of the most important contributions of Ukrainian Canadian ethnographers has been the development of more nuanced understandings of and terminology regarding diverse trends and motivations, and thus divergent sub-subcultures within the immigrant/ethnic community.

In late Soviet and post-Soviet periods, the connections between Ukrainian ethnographers and Ukrainian Canadian ethnographers have become somewhat closer, with personnel travelling more often in both directions for conferences and fieldwork. A growing number of publications in Ukraine have dealt with Ukrainian Canadian content or have included Canadian contributors. In 2010 a special issue (Nahachevs'kyi et al.) of Narodoznavchi zoshyty (The Ethnology Notebooks, Lviv) was dedicated to Ukrainian folkloristics in Canada; the translations of selected Canadian publications into Ukrainian therein made them accessible to many readers in Ukraine for the first time. International projects and co-publications have increased (cf. Zubryts'kyi). Ukrainian ethnographer Maryna Hrymych, who spent two years in Canada, has initiated special volumes focusing on Klymasz's and Medwidsky's scholarly works (Klymasz, Ukrains'ka; Hrymych). Institutions and projects for the study of the Ukrainian diaspora have been established in Kyiv, Lviv, Ostroh, and other Ukrainian cities.

\section{Major ContRiBUtions AND POTENTIALS OF UKRAINIAN CANADIAN ETHNOGRAPHY}

The contributions of Ukrainian Canadian ethnography to Canadian ethnography have generally been cumulative rather than monumental. Klymasz's contributions to theories of ethnic folklore have been the most often cited in North America. ${ }^{2}$ Publications and presentations about Ukrainian subject matter have played a proportional role in North American

\footnotetext{
2 Indicated by exploratory searches of the online Thomson Reuters "Cited Reference Search," Nov. 2016.
} 
ethnography and have contributed to a general awareness of the existence of Ukraine and Ukrainian culture. Ukrainian Canadian ethnographers other than Klymasz have been more well-known in association with their specific research subjects: Rudnyckyj perhaps for his published collection of texts and onomastics; Medwidsky for proverbs, verbal lore, historiography, and his organizing/fundraising skills; Kononenko for kobzar traditions, postSoviet ritual, and vernacular spiritual culture; Nahachewsky primarily as an ethnochoreologist and for writing about intangible cultural heritage; and Bilash for material culture and open-air museum curation. Younger scholars such as Cherwick, Khanenko-Friesen, Kukharenko, Lesiv, Ostashewski, and Oylupinar have been expanding the subject matter and theoretical perspectives actively.

In Ukraine the most popular two Ukrainian Canadian ethnographic publications seem to be those by Kylymnyk and Metropolitan Ilarion. ${ }^{3}$ Both were republished in Kyiv in 1994 and are available in full text on multiple websites. This is striking, and likely disappointing for many scholars, as these publications are far from the main productive threads in Ukrainian Canadian ethnography. Furthermore, they are not comfortably endorsed by most academic ethnographers in either country. Rather they are most popular among supporters of "native faith" communities such as RUNvira and Ridna vira. Canada and the United States have certainly played a role in the history of these native faith movements, but mostly before Ilarion's book appeared in 1965. These movements have expanded greatly in Ukraine in the post-Soviet period, and it is in Ukraine that these books have their greatest readership half a century after their appearance (cf. Lesiv, The Return).

Ilarion's and Kylymnyk's books demonstrate that Ukrainian ethnographic scholarship and Ukrainian Canadian ethnographic scholarship are generally unsynchronized and are not attuned to the same issues at the same time. The dominant Canadian themes of contextual sensitivity and adaptation, diasporan content, transculturalism, innovation and hybridity, engagement with global cultural flows, urban culture, subcultures in contemporary life, and digital culture are all quite marginal to ethnology and folkloristics in Ukraine, whereas many (not all) Ukrainian ethnographers continue to explore ancient origins, Ukrainian unity, and cultural stability.

Given several new translations, publications, and collaborations in Ukraine, an increased knowledge of English, and a new generation of ethnographers with increased mobility and international perspectives, there is now a growing capacity for further, increased interaction between

\footnotetext{
${ }^{3}$ Indicated by a cursory investigation on Google, where a search for Kylymnyk's title in Cyrillic, for example, produces tenfold more results than the other titles in the bibliography below (approx. 133,000 in Nov. 2016).
} 
Ukrainianist ethnographers in Canada and Ukraine. Ethnographers in Ukraine may add Ukrainian Canadian subject matter and conceptual threads to their arsenal of tools for understanding culture. Canadian Ukrainian ethnography has potential to contribute significantly to Ukrainian scholarship in a post-romantic and softened national light, if that is desired. More scholars in Ukraine may wish to focus on Ukrainian culture in a multicultural context; to observe unofficial and minority contemporary culture, with its complex of cultural processes; to elaborate with nuance on how identity and ethnicity are cultural resources managed strategically in diverse settings; and to study subcultures (in addition to the traditional ethnographic regions) in alternative temporal and spacial dimensions. In these areas and others, Canadian Ukrainian ethnography has potential to contribute significantly.

\section{Works Cited}

Balan, Jars. Salt and Braided Bread: Ukrainian Life in Canada. Oxford UP, 1984.

Berthiaume-Zavada, Claudette. "Le Chant Ukrainien, une Puissance Qui Défie les Pouvoirs." Dissertation, University of Montreal, 1994.

Bezborodova, Nataliya. "Maidan on Facebook: Sensitive, Expressive and Interpretative Protest Lore." MA thesis, University of Alberta, 2016.

Bilash, Radomir. "The Colonial Development of East Central Alberta and Its Effect on Ukrainian Immigrant Settlement to 1930." MA thesis, University of Manitoba, 1983.

---, and Barbara Wilberg. Tkanyna: An Exhibit of Ukrainian Weaving. Research by Ruth Lysak-Martynkiw and Nadia Kreptul. Canadian Institute of Ukrainian Studies and Friends of the Ukrainian Village Society, 1988.

Boichuk [Boychuk], Volodymyr. Vesil'ni pisni ukraintsiv Bosnii. Kanads'ke ob"iednannia ukraintsiv kolyshn'oi Iuhoslavii, 2006. Translation of "VivadyWedding Songs of Ukrainians from Bosnia," MA thesis, University of Alberta, 1997.

Boulton, Laura. Ukrainian Winter Traditions. National Film Board of Canada, 1942.

Cheladyn, Larisa Sembaliuk. "Stitched Memories: The Ukrainian Canadian Embroidered Pillow." MA thesis, University of Alberta, 2016.

Chernevych, Andriy. "Malanka Through the Back Door: Ukrainian New Year's Eve Celebration in East Central Alberta." MA thesis, University of Alberta, 2002.

Cherniavs'ka (Chernyavska), Maryna. "Arkhiv ukrains'koho fol'kloru Bohdana Medvids'koho." Proverbs in Motion: A Festschrift in Honour of Bohdan Medwidsky (Prykazky v dii: Zbirnyk na poshanu Bohdana Medvids'koho), edited by Andriy Nahachewsky and Maryna Chernyavska, Canadian Institute of Ukrainian Studies P and Kule Centre for Ukrainian and Canadian Folklore, 2014, pp. 88-97.

Cherwick, Brian. "Polkas on the Prairies: Ukrainian Music and the Construction of Identity." Dissertation, University of Alberta, 1999.

---. "Whose Sunshine Are You? Folklorization, Commodification and the Root of a Song." Proverbs in Motion: A Festschrift in Honour of Bohdan Medwidsky (Prykazky 
$v$ dii: Zbirnyk na poshanu Bohdana Medvids'koho), edited by Andriy Nahachewsky and Maryna Chernyavska, Canadian Institute of Ukrainian Studies P and Kule Centre for Ukrainian and Canadian Folklore, 2014, pp. 197-221.

Chorniawy, Cathy. Commerce in the Country: A Structural History of the Luzan Grocery Store. Alberta Culture and Multiculturalism, Historical Resources Division, 1989. Alberta Historic Sites Service Occasional Paper 17.

Chumer, Vasyl'. Spomyny pro perezhyvannia pershykh ukrains'kykh pereselentsiv $v$ Kanadi, 1892-1942. 1942. Translated by William A Czumer, Recollections About the Life of the First Ukrainian Settlers in Canada, Canadian Institute of Ukrainian Studies, 1981.

Evasiuk, Nick. "Nick Evasiuk Collection: Ukrainian Tales, Some Clean, Some Obscene." Bohdan Medwidsky Ukrainian Folklore Archives, UF2016.12.

Fedyk, Teodor. Pisni imigrantiv pro staryi i novyi krai (Pisni pro Kanadu i Avstriiu). 1911. Ukrains'ka knyharnia, 1927.

Fodchuk, Roman. Zhorna: Material Culture of the Ukrainian Pioneers. U of Calgary P, 2006.

Foty, George. "A Survey of the Mythology of Kievan Rus' and Its Survivals in the Folklore of the Eastern Slavs." MA thesis, University of Alberta, 1963.

Foty, Nadya. "Ukrainian Mock Weddings in Saskatchewan." MA thesis, University of Alberta, 2003.

Fujiwara, Aya. "Ethnicity and Local Community Building: The Opal/Maybridge Farm Settlement in East-Central Alberta, 1919-1945." MA thesis, University of Alberta, 2000.

Hanchuk, Rena Jeanne. The Word and Wax: A Medical Folk Ritual Among Ukrainians in Alberta. Canadian Institute of Ukrainian Studies P, 1999. Originally "The Word and Wax: Folk Psychology and Ukrainians in Alberta." MA thesis, University of Alberta, 1990.

Himka, John-Paul, et al. "Update on Sanctuary: The Spiritual Heritage Documentation Project." Forum for Ukrainian Studies, http://ukrainianstudies.ca/2015/05/11/update-on-sanctuary-the-spiritual-heritagedocumentation-project/. Accessed 1 Aug. 2016.

Hnatiuk, Volodymyr. "Pisenni novotvory v ukrains'ko-rus'kii narodnii slovesnosti." Zapysky NTSh, vol. 50, no. 6, 1902, pp. 1-37, and vol. 52, no. 11, 1903, pp. 38-67.

Holoborodko, Vita. "Custodians of Ukrainian Heritage: Three Ukrainian Museums in Edmonton." MA thesis, University of Alberta, 2004.

Hong, Sogu. "Ukrainian Canadian Weddings As Expressions of Ethnic Identity: Contemporary Edmonton Traditions." Dissertation, University of Alberta, 2005.

Hrymych, Maryna. Narysy z ukrains'ko-kanads'koi fol'klorystyky: Bohdan Medvids'kyi. Duliby, 2016.

---, et al. Ukraintsi Brazylii / Os ucranianos do Brasil / Ukrainians in Brazil: A HistoricEthnologic Study. Duliby, 2011.

Hunchuck, Suzanne Holyk. "A House Like No Other: An Architectural and Social History of the Ukrainian Labour Temple, 523 Arlington Avenue, Ottawa, 19231967." MA thesis, Carleton University, 2001.

Ianiv, Volodymyr, editor. Zbirnyk na poshanu Zenona Kuzeli. Zapysky NTSh, vol. 169, 1962. 
Ilarion, Metropolitan (Ivan Ohiienko). Dokhrystyians'ki viruvannia ukrains'koho narodu: Istorychno-relihiina monohrafiia. Research Institute of Volhyn, 1965; Oberehy, 1994.

Jensen, Monica. "Personal Narratives and Ritual Observance: How Personal Narratives Based on Ritual Observance Shaped the Family Identities of Two Groups of Second-Generation Ukrainian Canadian Sisters." Dissertation, University of Alberta, 2005.

Khanenko-Friesen Natalia (Khanenko-Frizen, Nataliia). Inshyi svit abo etnichnist' $u$ dii: Kanads'ka ukrains'kist' kintsia dvadtsiatoho stolittia. Smoloskyp, 2011.

---. Ukrainian Otherlands: Diaspora, Homeland, and Folk Imagination in the Twentieth Century. U of Wisconsin P, 2015. Folklore Studies in a Multicultural World.

Klymasz, Andrea. "Folk Medicine: A Ukrainian Canadian Experience." MA thesis, University of Manitoba, 1991

Klymasz, Robert B. A Bibliography of Ukrainian Folklore in Canada, 1902-1964. Queen's Printer, 1969.

---. Continuity and Change: The Ukrainian Folk Heritage in Canada. National Museums of Canada, Canadian Centre for Folk Culture Studies, 1972.

---. "Crucial Trends in Modern Ukrainian Embroidery." Material History Bulletin, no. 26, 1987, pp. 1-6.

---. "Folklore Politics in the Soviet Ukraine: Perspectives on Some Recent Trends and Developments." Journal of the Folklore Institute, vol. 12, no. 2/3, 1975, pp. 17788.

---. "Gimli Community Research Project." University of Manitoba, Archives of the Ukrainian Canadian Experience, Robert Klymasz Fonds, A.02-32. 2002.

---. Luchak's Easter. National Museum of Man / National Film Board of Canada, 1975.

--. "Male and Female Principles As Structure in the Ritual Foodways of Ukrainians in Canada." Journal of Ukrainian Studies, vol. 10, no. 2, 1985, pp. 15-27.

---. Svieto: Celebrating Ukrainian Canadian Ritual in East Central Alberta Through the Generations. Edited by Radomir Bilash, Alberta Culture and Multiculturalism, Historical Resources Division, 1992. Alberta Historic Sites and Archives Service Occasional Paper 21.

---. "Ukrainian Folklore in Canada: An Immigrant Complex in Transition." Dissertation, Indiana University, 1971. Published by Arno Press, 1980.

---, compiler. Ukrainian Folksongs from the Prairies. With the participation of Andrij Hornjatkevyč, et al., Canadian Institute of Ukrainian Studies, 1992. Occasional Research Report 52.

--- (Klymash, Bohdan). Ukrains'ka narodna kul'tura $v$ kanads'kykh preriiakh. Translated and edited by Svitlana Kukharenko, Duliby, 2013.

---. "University Graduate Dissertations Produced from 1925 to 2005 Relating to the Ukrainian Experience in Canada." Research on Ukrainian Canadiana, Centre for Ukrainian Canadian Studies, University of Manitoba, 2005. http://umanitoba.ca/faculties/arts/departments/ukrainian canadian studies/r esearch/index.html. Accessed 1 Aug. 2016.

Kod, Kateryna. "Ethnocultural Identity and Edmonton Painters Recently from Ukraine." MA project, University of Alberta, 2016.

Kolessa, Filiaret. Ukrains'ka usna slovesnist'. 1938. Introduction by Mykola Mushynka, Canadian Institute of Ukrainian Studies, 1983. 
Kononenko, Natalie. "Ukrainian Ballads in Canada: Adjusting to Life in a New Land." Canadian Slavonic Papers, vol. 50, no. 1-2, 2008, pp. 17-36.

---. “Ukrainian Folklore in Kazakhstan." Folklorica, vol. 16, 2011, pp. 163-83.

---. Ukrainian Minstrels: And the Blind Shall Sing. M. E. Sharpe, 1998.

Kostash, Myrna. All of Baba's Children. Hurtig, 1977.

Koszarycz, Anna-Marie. "Collection and Documentation of Ukrainian Folk Songs in Kalyna Country, Edmonton, Alberta, Canada (1997)." MMus thesis, University of Calgary, 1999.

Kravchuk, Petro [Krawchuk, Peter]. Nasha stsena: Khudozhnia samodiial'nist' ukrains'kykh poselentsiv u Kanadi. Kobzar, 1981.

Kukharenko, Svitlana. "Abnormal Death Memorials in Ukraine: The Folkloristic Perspective." Dissertation, University of Alberta, 2010.

---. "Negotiating Magic: Ukrainian Wedding Traditions and Their Persistence in Canada." Canadian Slavonic Papers, vol. 50, no. 1-2, 2008, pp. 55-74.

---, and Peter Holloway, editors. The Paths of Folklore: Essays in Honor of Natalie Kononenko. Slavica, 2012.

Kuranicheva, Anna. "Art and Ethnicity: The Expression of Ukrainian Identity Through Art Objects Displayed in the Home." MA thesis, University of Alberta, 2002.

Kylymnyk, Stepan. Ukrains'kyi rik u narodnykh zvychaiakh $v$ istorychnomu osvitlenni. Tryzub, 1955-64, 5 vols; Oberehy, 1994, 2 vols.

Lazarowich, Linda Marie. "A Social History of Ukrainian Cottage Weaving in Alberta, 1900 to 1940." MA thesis, University of Manitoba, 1984.

Lehr, John C. Community and Frontier: A Ukrainian Settlement in the Canadian Parkland. U of Manitoba P, 2011.

---. "The Process and Pattern of Ukrainian Rural Settlement in Western Canada, 18911914." Dissertation, University of Manitoba, 1978.

---. Ukrainian Vernacular Architecture in Alberta. Historical Resources Division, 1976. Alberta Historic Sites Service Occasional Paper 1.

Lesiv, Mariya. "From Ritual Object to Art Form: The Ukrainian Easter Egg Pysanka in Its Canadian Context." Folklorica, vol. 12, 2007, pp. 1-32.

---. The Return of Ancestral Gods: Modern Ukrainian Paganism As an Alternative Vision for a Nation. McGill-Queen's UP, 2013.

Lesoway, Marie. Out of the Peasant Mold: A Structural History of the M. Hawryliak Home in Shandro, Alberta. Alberta Culture and Multiculturalism, Historical Resources Division, 1989. Alberta Historic Sites Service Occasional Paper 16.

Livesay, Florence Randal. Songs of Ukraina. Dent, 1916.

Lohvyn, Viktoriia [Lohvin, Victoria]. "Ukrains'ke zvychaieve pravo: Proba analizu deiakykh aspektiv zhinochoho prava." Dissertation, University of Alberta, 1997.

Lupul, Manoly R., editor. Continuity and Change: The Cultural Life of Alberta's First Ukrainians. Canadian Institute of Ukrainian Studies / University of Alberta / Historic Sites Service, Alberta Culture and Multiculturalism, 1988.

---. Heritage in Transition: Essays in the History of Ukrainians in Canada. McClelland and Stewart, 1982.

---. Visible Symbols: Cultural Expression Among Canada's Ukrainians. Canadian Institute of Ukrainian Studies, 1984.

Major, Alice. Ukrainian Shumka Dancers: Tradition in Motion. Reidmore Books, 1991. 
Makar, Alexander and Radomir Bilash, editors. Migrations from Western Ukraine to Western Canada: Proceedings of the Joint Conferences. Alberta Historic Sites Service and the Canadian Centre for Ukrainian Culture and Ethnography, 2002.

Maruschak, Lesia. "The Ukrainian Wedding: An Examination of Its Rites, Customs and Traditions." MA thesis, University of Saskatchewan, 1985.

Matiash, Iryna. Arkhivna ukrainika v Kanadi: Dovidnyk (Archival Ucrainica in Canada: A Guide). Derzhavnyi komitet arkhiviv Ukrainy / Ukrains'kyi naukovo-doslidnyi instytut arkhivnoi spravy ta dokumentoznavstva / Canadian Institute of Ukrainian Studies, 2010.

Matiasz, Sophia. "Ukrainian Catholics and Catholic Ukrainians: Ethnicity and Religion in Three Urban Alberta Parishes.” Dissertation, University of Alberta, 1994.

Medvids'kyi (Medwidsky), Bohdan. "Katedra ukrains'koi kul'tury ta etnohrafii im. Hutsuliakiv pry Al'berts'komu universyteti: Kontekstual'na analiza." Zakhidn'okanads'kyi zbirnyk, edited by Yar Slavutych, vol. 3, 1998, pp. 40-87.

---. "Na odnomu misti khrestiv dvisti." Narodna tvorchist' ta etnohrafiia, no. 6, 1991, pp. 16-20.

---. "Zbyrannia i vyvchennia ukrains'koho fol'kloru v Kanadi." Narodna tvorchist' ta etnohrafiia, no. 2, 1991, pp. 41-52.

Melnyk, John Alexander. "A Typology of Ukrainian Canadian Folklore." MA thesis, University of Manitoba, 1972.

Moroz, Valentyn. "Ukrains'ka lira: Pytannia kharakteru ta pokhodzhennia iavyshcha." MA thesis, University of Alberta, 1989.

Mucz, Michael. Baba's Kitchen Medicines: Folk Remedies of Ukrainian Settlers in Western Canada. U of Alberta P, 2012.

Nahachewsky, Andriy. "Avramenko and the Paradigm of National Culture." Journal of Ukrainian Studies, vol. 28, no. 2, 2003, pp. 31-50.

---. "The Kolomyika: Change and Diversity in Canadian Ukrainian Folk Dance." Dissertation, University of Alberta, 1991.

---. Local Culture and Diversity on the Prairies: A Project Report. Friends of the Ukrainian Folklore Centre, 2005.

---, and Maryna Chernyavska, editors. Proverbs in Motion: A Festschrift in Honour of Bohdan Medwidsky. Canadian Institute of Ukrainian Studies and the Kule Centre for Ukrainian and Canadian Folklore, 2014.

---. "Searching for Branches, Searching for Roots: Fieldwork in My Grandfather's Village." Dance in the Field: Theory, Methods and Issues in Dance Ethnography, edited by Theresa Buckland, Macmillan, 1999, pp. 175-85. Ukrainian translation: "U poshukakh vittia, u poshukakh koreniv: Pol'ovi doslidzhennia v selyshchi moho didusia." Narodoznavchi zoshyty, no. 3-4 (93-94), 2010, pp. 454-60.

Nahachevs'kyi, Andrii (Nahachewsky, Andriy). "Fol'klor ukraintsiv Kanady u doslidzhenniakh aspirantiv kanads'kykh universytetiv." Zakhidn'okanads'kyi zbirnyk, vol. 6, 2012, pp. 103-12.

---, and Mariia Maierchyk. "Osoblyvosti ukrains'koi fol'klorystyky v Kanadi." Narodoznavchi zoshyty, no. 3-4 (93-94), 2010, pp. 293-309.

---. Pobutovi tantsi kanads'kykh ukraintsiv, Rodovid, 2001. Translation of "First Existence Folk Dance Forms Among Ukrainians in Smoky Lake, Alberta, and Swan Plain, Saskatchewan.” MA thesis, University of Alberta, 1985. 
---, et al. Ukrains'ka fol'klorystyka v Kanadi: Novi vizii tradytsiinoho, tradytsiini vizii novoho. Special issue, Narodoznavchi zoshyty, no. 3-4 (93-94), 2010.

Niniowsky, Wasyl. "The Poetic Forms and Mythological Elements in the Ukrainian Hutsulian Carols-Koliadky and Shchedrivky." MA thesis, University of Alberta, 1967.

Odarchenko, Petro, et al. Ukrains'kyi narodnii odiah. World Federation of Ukrainian Women's Organizations, Folk Art Commission, 1992.

Olijnyk, Paul. "Hutsul Dance Steps." MA thesis, University of Alberta, 2013.

Onyshchuk, Odarka. Symvolika ukrains'koi pysanky. 1985.

Osborn, Laurel. "Lullabies of Ukraine in the Context of Ukrainian Folksong Tradition: A Textual and Musical Analysis of the Repertory from the Zinoviy Lys'ko Collection, Ukrainian Folk Melodies, 1967." Dissertation, University of Saskatchewan, 1995.

Ostashewski, Marcia. "Performing Heritage: Ukrainian Festival, Dance and Music in Vegreville, Alberta." Dissertation, York University, 2009.

Oylupinar, Huseyin. "Remaking Terra Cossacorum: Kozak Revival and Kozak Collective Identity in Independent Ukraine." Dissertation, University of Alberta, 2014.

Peacock, Kenneth. A Survey of Ethnic Folkmusic Across Western Canada. National Museum of Canada, 1963. Anthropology Papers 5.

Piniuta, Harry, researcher and translator. Land of Pain, Land of Promise: First Person Accounts by Ukrainian Pioneers, 1891-1914. Western Producer Prairie Books, 1981.

Plaviuk, Volodymyr (Plawiuk), collector. Prypovidky, abo ukrains'ko-narodnia filosofiia. 1946. Reprinted in Pioneers' Association of Alberta, 1998.

---. Ukrains'ki prypovidky. Edited by Bohdan Medvids'kyi and Oleksander Makar, Huculak Chair of Ukrainian Culture and Ethnography at the University of Alberta and the Ukrainian Pioneers Association of Alberta, 1996.

Pritz, Alexandra. "Ukrainian Cultural Traditions in Canada: Theatre, Choral Music and Dance, 1891-1967." MA thesis, University of Ottawa, 1977.

Rozumnyj, Jaroslav, editor. New Soil-Old Roots: The Ukrainian Experience in Canada. Ukrainian Academy of Arts and Sciences in Canada, 1983.

Rudnyckyj, Jaroslav B. (Rudnyts'kyi, Iaroslav B). Materiialy do ukrains'ko-kanadiis'koi folkl'orystyky i diialektolohii. Ukrainian Free Academy of Sciences, 1956-63. 4 vols. (Vol. 3 [1960] presents selected texts in English translation.)

Scott, J. Marilyn. Mandolin Mosaic: Roots... Stories... Songs.... St. Nicholas Mandolin Ensemble. St. Nicholas Mandolin Ensemble Society, 2013.

Shaw, Sylvia. "Attitudes of Canadians of Ukrainian Descent Towards Ukrainian Dance." Dissertation, University of Alberta, 1988.

Shiyan, Roman. "Cossack Treasures in Ukrainian Folk Legends.” Folklorica, vol. 13, 2008, pp. 75-96.

Shostak (now Khanenko-Friesen), Natalia. "Local Ukrainianness in Transnational Context: An Ethnographic Study of a Canadian Prairie Community." Dissertation, University of Alberta, 2001.

Shostok ( sic $=$ Shostak, now Khanenko-Friesen), Natalia. "The Ukrainian Peasant Home: Space Domestication." Vernacular Architecture, special issue, Canadian Folklore, vol. 17, no. 2, 1995, pp. 51-69. 
Sinclair, Pamela Joan. "Hidden on the Farm: Remembrances of a Ukrainian Canadian Immigrant Farm Woman." MA thesis, Simon Fraser University, 1996.

Sochan, Anne Marechko. "Continuity and Change: An Intergenerational Examination of Ukrainian Christmas Observances in East Central Alberta." MA thesis, University of Alberta, 1992.

Stechishin, Savella. Traditional Ukrainian Cookery. Drawings by Wadym W. Dobrolige, Trident Press, 1957; 18th ed., 1995.

Swyripa, Frances. Guide to Ukrainian Canadian Newspapers, Periodicals, and Calendar-Almanacs on Microfilm, 1903-1970. Canadian Institute of Ukrainian Studies, 1985. Occasional Research Report 8.

---. Oral Sources for Researching Ukrainian Canadians: A Survey of Interviews, Lectures and Programmes Recorded to December 1980. Canadian Institute of Ukrainian Studies, 1985. Occasional Research Report 11.

---. Storied Landscapes: Ethno-Religious Identity and the Canadian Prairies. U of Manitoba P, 2010.

Tarnawsky, George and Patricia Kilina, translators. Ukrainian Dumy: Editio Minor. Canadian Institute of Ukrainian Studies and Harvard Ukrainian Research Institute, 1979.

Tracz, Orysia. First Star I See Tonight: Ukrainian Christmas Traditions. Mazepa, 2015.

The Ukrainian Canadians. Special issue, Canadian Ethnic Studies Journal, guest edited by Natalia Aponiuk, vol. 47, no. 4-5, 2015.

Ukrainians in Canada. Special issue, Journal of Ukrainian Studies, guest edited by Frances Swyripa, vol. 16, no. 1-2, 1991.

The Ukrainians in Canada, 1891-1991. Special issue, Material History Bulletin, guest edited by Robert B. Klymasz, no. 29, 1989.

Wynnyckyj, Iroida. "Ukrainian Canadian Drama from the Beginnings of Immigration to 1942." MA thesis, University of Waterloo, 1976.

Yakovlyeva, Viktoriya. "Childhood After Chornobyl: A Social History of Childhood in Ukraine, 1986-1996." Dissertation, University of Alberta, 2016.

Zaporzan, Shirley and Robert B. Klymasz. Film and the Ukrainians in Canada, 19211980: A Filmography Index of Film Titles and Bibliography with Supplementary Appendices. Additional entries by Jars Balan. Canadian Institute of Ukrainian Studies, 1982. Occasional Research Report 1.

Zembrzycki, Stacey. According to Baba: A Collaborative Oral History of Sudbury's Ukrainian Community. UBC P, 2014.

Zubryts'kyi, Mykhailo. Naukovi pratsi. Zibrani tvory u tr'okh tomakh, edited by Frank Sysyn et al., vol. 1, Litopys, 2013. 